\title{
AVAILABILITY TO PUBLIC AND PRIVATE GOODS AND SERVICES AS ELEMENT OF SUSTAINABLE DEVELOPMENT OF RURAL AREAS
}

\author{
Barbara Prus, Tomasz Salata, Krzysztof Gawroński \\ Agricultural University in Krakow, Poland \\ b.prus@ur.krakow.pl,rmtsalat@cyf-kr.edu.pl,k.gawronski@ur.krakow.pl
}

\begin{abstract}
The level of socio-economic development of settlement units depends on the functions performed by these units in functional hierarchy of the rural settlement system in the range of public service. As a settlement system, a registration unit - in this case equal to the definition of a commune (the smallest surface administrative unit in Poland) was taken into account, whereas a cadastral region was considered as a settlement unit. Among locations that form the settlement system, elementary units with poorly developed social infrastructure system, basic units as well as over primary ones, which are the highest-ranking in functional hierarchy units bestequipped in public service, can be identified. The research thesis of this paper is to prove that units from the higher level of hierarchy develop faster and more efficiently and also have higher development level than elementary units. The aim of the paper is to analyse the functional structure of selected rural settlement system in order to determine hierarchy of settlement units and then to confront the obtained results with socio-economic development specified by means of spatial taxonomy methods recorded in the form of a synthetic metha-index. In this article, qualitative methods, in particular analyses and logical constructions, including identification were used. The methods were applied to consolidate the analyzed problem and propose optimal solutions. The comparative analysis and analyses of relevant literature were also used to highlight the research problem. The surveys were performed taking the chosen rural communes located in Małopolska province in Southern Poland into consideration.
\end{abstract}

Keywords: multifunctional development, hierarchy in rural settlement system, access to goods and services.

\section{Introduction}

McGranahan writes that attracting people in rural areas usually depends on the availability and quality of natural resources, schools and access to public and private goods and services [1]. The number, kind and location of customer service points are conditioned by citizens' direct demand [2]. And variety of social infrastructure elements at rural areas results also, among other things, from premises of so called multifunctional development of rural areas implemented from several decades in the area of Europe $[3 ; 4]$. The development of social and engineering infrastructure in rural areas, as a component of sustainable development $[5,6]$, is one of the most important problems in the world [710]. Structural changes in traditional rural employment sectors, e.g., agriculture or manufacturing challenge the future of rural communities as places to live and work [11]. It is remarkable that rural communities with attractive lifestyle and educated workforce or these situated near a larger urban place have income growth [12], but communities with smaller populations and relatively low fiscal capacity have not maintained historic levels of population or employment [13]. Social development including access to services is an essential part of efforts towards poverty reduction [14].

Settlement units compose separated from space systems, which create local environment of inhabitants' life. These structured spatial systems due to existing physiographic considerations and the form of housing are characterized by specific autonomy. Citizens staying in mutual relations create socio-economic space. This space is determined by the place of living and working as well as service centres and areas covered by providing services [15]. These tight connections between people and their territories create relations between settlement units and inhabitants, which is expressed by the process of relocation. Places of relocation within so-called usual places of residence are partly closed, hierarchically organized systems [16].

Surveys on morphogenesis of rural settlements in Poland from the last few decades indicate occurrence of a great number of densely populated villages. The mixed type of settlement (that is connected, among other things, with a relief - a foothills area that is present at this area), which is characterized by the network of big and concentrated villages with dispersion on the periphery, dominates in the area of southern Poland. The second type of concentrated settlement as to the frequency of occurrence where big villages are predominant is situated in places of medieval forest-field villages [17]. In most cases, concentrated villages have a distinguishing settlement system with the axial system of estates [18]. Village spatial structure is modified and 
transformations include forms of agricultural land usage together with all accompanying elements [1921]. According to the $20^{\text {th }}$-century definition, a village is a settlement unit of small surface area and housing mainly of farmhouses with the significant part of inhabitants living off incomes from agriculture. In the area of Poland, this definition is not current in the vast majority of cases. Farmhouses are not predominant and people do not carry out farm work in the villages. However, new residential areas, enclaves of modern housing that do not refer by no means to typical architecture of rural landscape appearing over the last few years can be observed [21]. Emerging new forms of construction demonstrate some kind of continuity of spatial form and processes that take place in them which are defined by the concept of urban-rural continuum with difficult to explain variation and characteristic lack of borders $[19 ; 22]$. Together with developing new settlement housing, buildings connected with so-called social infrastructure that provides access to foods and services for inhabitants also appear in rural landscape.

The level of socio-economic development of settlement units depends on functions performed by these units in functional hierarchy of rural settlement system in the range of public service [23]. Among locations that form the settlement system, elementary units with poorly developed social infrastructure system, basic units as well as over primary ones which are the highest-ranking in functional hierarchy units best-equipped in public service can be distinguished. The research thesis of this paper is to prove that units from the higher level of hierarchy develop faster and more efficiently and also have higher development level than elementary units.

\section{Materials and methods}

Subjective evaluation of settlement units (villages) as regards the function they fulfil in the hierarchy of the functional structure of settlement network was performed (a commune understood as the smallest surface administrative unit in Poland).

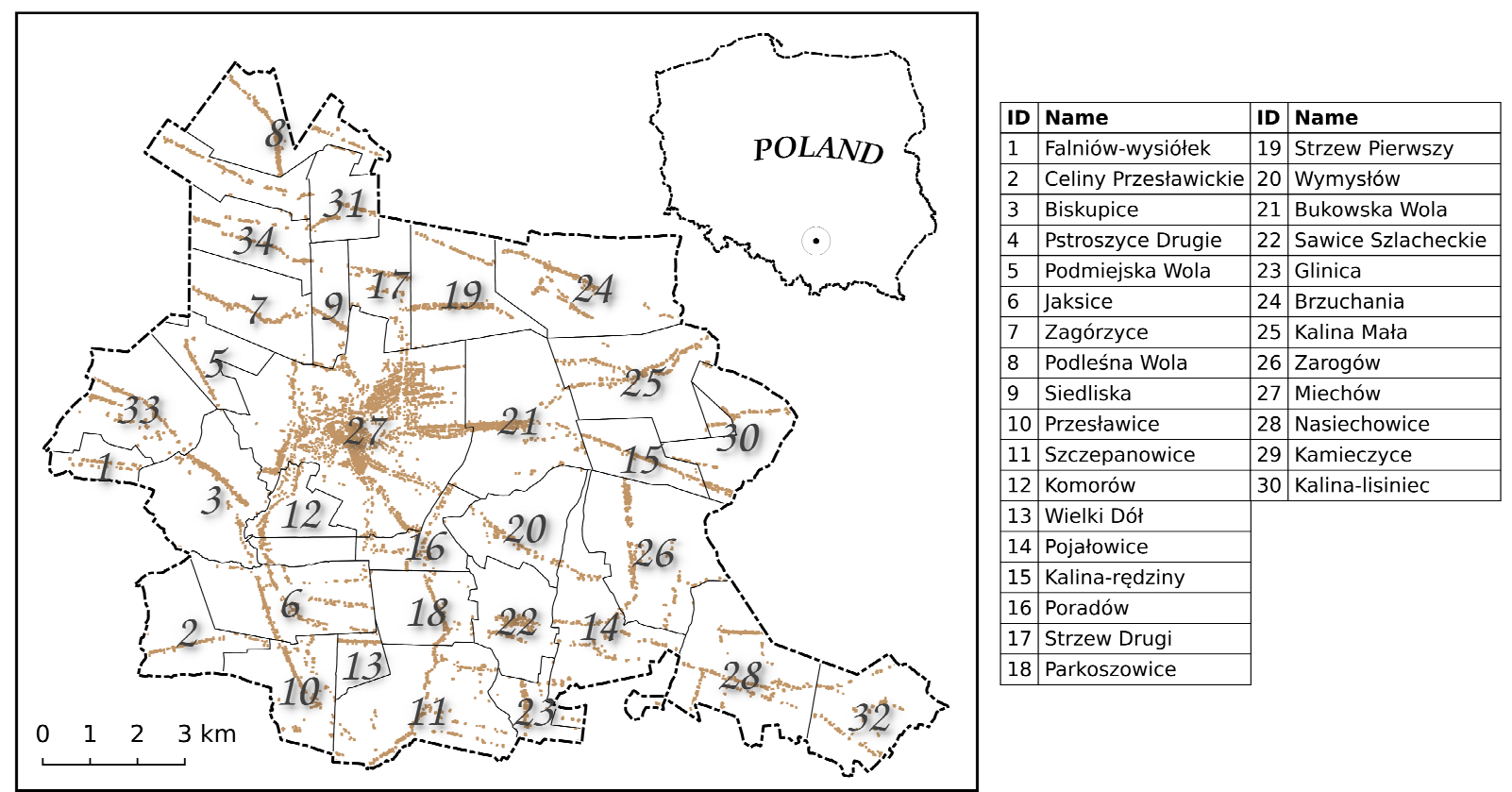

\section{Fig. 1. Spatial arrangement of administrative units in Miechów commune} on the grounds of housing distribution

Spatial arrangement of individual administrative units on the grounds of the analysed commune can be seen in Figure 1. On the basis of numbers of population and points of people and agriculture service as well as availability of communication and taking into consideration the historical aspect, division of units according to their fulfilled functions in functional hierarchy of rural settlement network was determined. Using the method of competent judges and mainly on the basis of knowledge of local conditions and also socio-economic dependencies fulfilled by places in the range of population and agriculture services as well as communication premises, arbitrary division of units into elementary, basic and higher ones was performed. The introduced division of settlement units into 
elementary, basic and higher ones presents the hierarchy of the functional structure of the rural settlement network in Poland. Settlement units are the lowest link in the hierarchy - they mainly consist of homesteads, a little number of points that compose the social infrastructure possibly occurs there. Basic units provide service to other basic units, whereas higher units stand out by the highest number of points of social infrastructure. In most cases, a higher unit is a commune. With regard to the above-mentioned division, the following weights were arbitrarily attributed to individual levels according to the assumption: the higher unit -3 , the basic unit -2 , the elementary unit -1 .

The aim of the paper is to analyse the functional structure of the selected rural settlement system in order to determine the hierarchy of settlement units and then to confront the obtained results with socio-economic development of the settlement units. The analysis of internal developments of individual objects was determined by data availability. All data were obtained directly from databases of field objects. The set of variables presenting demographic, socio-economic and natural conditions including the number of inhabitants, the area of farmland, the area of lands with the highest productive value, the area of forest, the area of built-up and urbanized lands, the area of transport grounds, the number of residential buildings, the number of buildings used for agricultural production, the number of education, culture and science buildings as well as service and sales points were accepted to be analysed. The analysed variables were subjected to the process of standardisation by means of a mean value [24]. Then, the total metha-index was calculated. The synthetic coefficient of development was divided into four-class sections [25]. Creating the class sections, the arithmetic mean $\left(R_{a m}\right)$ of the obtained estimations of synthetic sizes and the coefficient of development level for every commune as well as the standard deviation were used assuming that the communes were distinguished by the following levels of development:
A. high, for which the condition $\left(R_{i}>R_{a m}+s\right)$ was fulfilled,
B. fairly high $\left(R_{a m}+s>R_{i}>R_{a m}\right)$,
C. average $\left(R_{a m}>R_{i}>R_{a m}-s\right)$,
D. low $\left(R_{a m}-s>R_{i}\right)$,

where $R_{i}$ - synthetic coefficient of development in a settlement

$R_{a m}$ - arithmetic mean of the synthetic coefficient of development

$s$ - standard deviation of the synthetic coefficient.

Correlative relation between the obtained values of the synthetic metha-index and the level in settlement unit hierarchy were calculated. The Guilford's scale was accepted to its evaluation. In this paper, qualitative methods, in particular analyses and logical constructions, including identification were used. The methods were applied to consolidate the analyzed problem and propose optimal solutions. The comparative analysis and analyses of relevant literature were also used to highlight the research problem. The surveys were performed taking commune Miechów located in Małopolska province in Southern Poland into consideration.

\section{Results and discussion}

The analysis of socio-economic conditions on the basis of set criteria allowed to separate four groups of objects with diverse level of development among settlement units in Miechów commune (Table 1). The highest level of socio-economic development has the town of Miechów. The obtained here synthetic metha-index reached the value of 115.8. Miechów was excluded from further evaluation of settlement units as the heterogenic unit. From among the remaining 33 settlement units - the places of rural character, slightly over $18 \%$ (6) of places were distinguished by the high level of development. The relatively high level was noted in case of $24 \%$ of villages (8). The most numerous group includes places with medium level, i.e. $39 \%$ (13), whereas the low level characterises $18 \%$ (6) of places.

The analysis of the spatial types of the places revealed that the bigger part of locations has got a compact housing type with a linear settlement or the Waldhufendorf ("forest village") street character. In the rural area, there are few service points for inhabitants that provide support for the social infrastructure. Among the analysed settlement units, Miechów was selected as the unit with higher level, which fulfils the demand for points of social infrastructure of the surrounding places and takes over transport of people that travel in order to provide their needs. It was accepted that 8 units 
(23.5\%) have the conditions fulfilled for the basic level (provide basic needs of inhabitants), whereas the remaining 25 units $(73.5 \%)$ are characterized by the elementary level - as in Table 1.

Table 1

Characteristics of settlement units in Miechów commune with determining their function in settlement network hierarchy

\begin{tabular}{|c|c|c|c|c|c|c|}
\hline No. & Name of unit & $\begin{array}{c}\text { Area of unit, } \\
\text { ha }\end{array}$ & $\begin{array}{c}\text { Number } \\
\text { of } \\
\text { buildings }\end{array}$ & $\begin{array}{c}\text { Unit level } \\
\text { in hierarchy } \\
\text { of functional rural } \\
\text { settlement } \\
\text { structure }\end{array}$ & $\begin{array}{l}\text { Synthetic metha- } \\
\text { index that } \\
\text { determines } \\
\text { the level of socio- } \\
\text { economic } \\
\text { development }\end{array}$ & $\begin{array}{l}\text { Socio- } \\
\text { economic } \\
\text { level }\end{array}$ \\
\hline 1. & Biskupice & 547.5173 & 104 & elementary & 7.373 & fairly high \\
\hline 2. & Brzuchania & 739.7783 & 99 & elementary & 12.918 & high \\
\hline 3. & Bukowska Wola & 713.5448 & 136 & basic & 10.093 & fairly high \\
\hline 4. & Celiny Przesławickie & 363.2550 & 47 & elementary & 10.359 & high \\
\hline 5. & Dziewięcioły & 457.5267 & 56 & elementary & 6.068 & average \\
\hline 6. & Falniów & 551.8979 & 87 & basic & 8.416 & fairly high \\
\hline 7. & Falniów-Wysiołek & 139.5714 & 26 & elementary & 2.956 & low \\
\hline 8. & Glinica & 167.2151 & 42 & elementary & 2.597 & low \\
\hline 9. & Jaksice & 545.3614 & 174 & basic & 12.321 & high \\
\hline 10. & Kalina Mała & 593.2961 & 134 & elementary & 8.092 & fairly high \\
\hline 11. & Kalina-Lisiniec & 393.7588 & 72 & elementary & 6.309 & average \\
\hline 12. & Kalina-Rędziny & 296.5585 & 69 & elementary & 5.587 & average \\
\hline 13. & Kamieńczyce & 118.9588 & 25 & elementary & 2.425 & low \\
\hline 14. & Komorów & 208.1144 & 53 & basic & 4.089 & average \\
\hline 15. & Miechów & 1547.0426 & 2001 & over primary & 115.857 & $\begin{array}{c}\text { beyond the } \\
\text { scale }\end{array}$ \\
\hline 16. & Nasiechowice & 692.9539 & 132 & basic & 15.442 & high \\
\hline 17. & Parkoszowice & 326.2637 & 62 & elementary & 6.824 & fairly high \\
\hline 18. & Podleśna Wola & 482.1281 & 120 & elementary & 7.210 & fairly high \\
\hline 19. & Podmiejska Wola & 251.9955 & 30 & elementary & 6.798 & fairly high \\
\hline 20. & Pojałowice & 548.6144 & 102 & basic & 6.366 & average \\
\hline 21. & Poradów & 229.0213 & 75 & elementary & 4.867 & average \\
\hline 22. & Przesławice & 366.8686 & 104 & elementary & 6.825 & fairly high \\
\hline 23. & Pstroszyce Drugie & 290.6357 & 55 & basic & 5.014 & average \\
\hline 24. & Pstroszyce Pierwsze & 338.2209 & 58 & basic & 5.857 & average \\
\hline 25. & Siedliska & 198.4677 & 45 & elementary & 2.928 & low \\
\hline 26. & Sławice Szlacheckie & 359.0235 & 66 & basic & 5.088 & average \\
\hline 27. & Strzeżów Drugi & 276.1000 & 76 & basic & 5.595 & average \\
\hline 28. & Strzeżów Pierwszy & 475.7345 & 105 & elementary & 6.649 & average \\
\hline 29. & Szczepanowice & 724.6807 & 155 & elementary & 11.477 & high \\
\hline 30. & Widnica & 251.8318 & 49 & elementary & 3.383 & low \\
\hline 31. & Wielki Dół & 114.3098 & 35 & elementary & 1.811 & low \\
\hline 32. & Wymysłów & 399.8299 & 55 & elementary & 4.896 & average \\
\hline 33. & Zagorzyce & 410.7014 & 76 & basic & 5.473 & average \\
\hline 34. & Zarogów & 694.9802 & 113 & elementary & 12.037 & high \\
\hline
\end{tabular}


The calculated rate of correlation between the synthetic metha-index that illustrates socioeconomic development of the tested places and the level of units in the hierarchy of the functional structure of rural settlement network indicates a relation at the level of 0.608 , which according to the Guilford's scale equals the high correlation.

The calculated rate is statistically significant. The coefficient of correlation with a positive sign means that together with the increase of the unit development level their position in the functional structure of the rural settlement network also raises, which is confirmed by conducted earlier surveys $[13 ; 26]$.

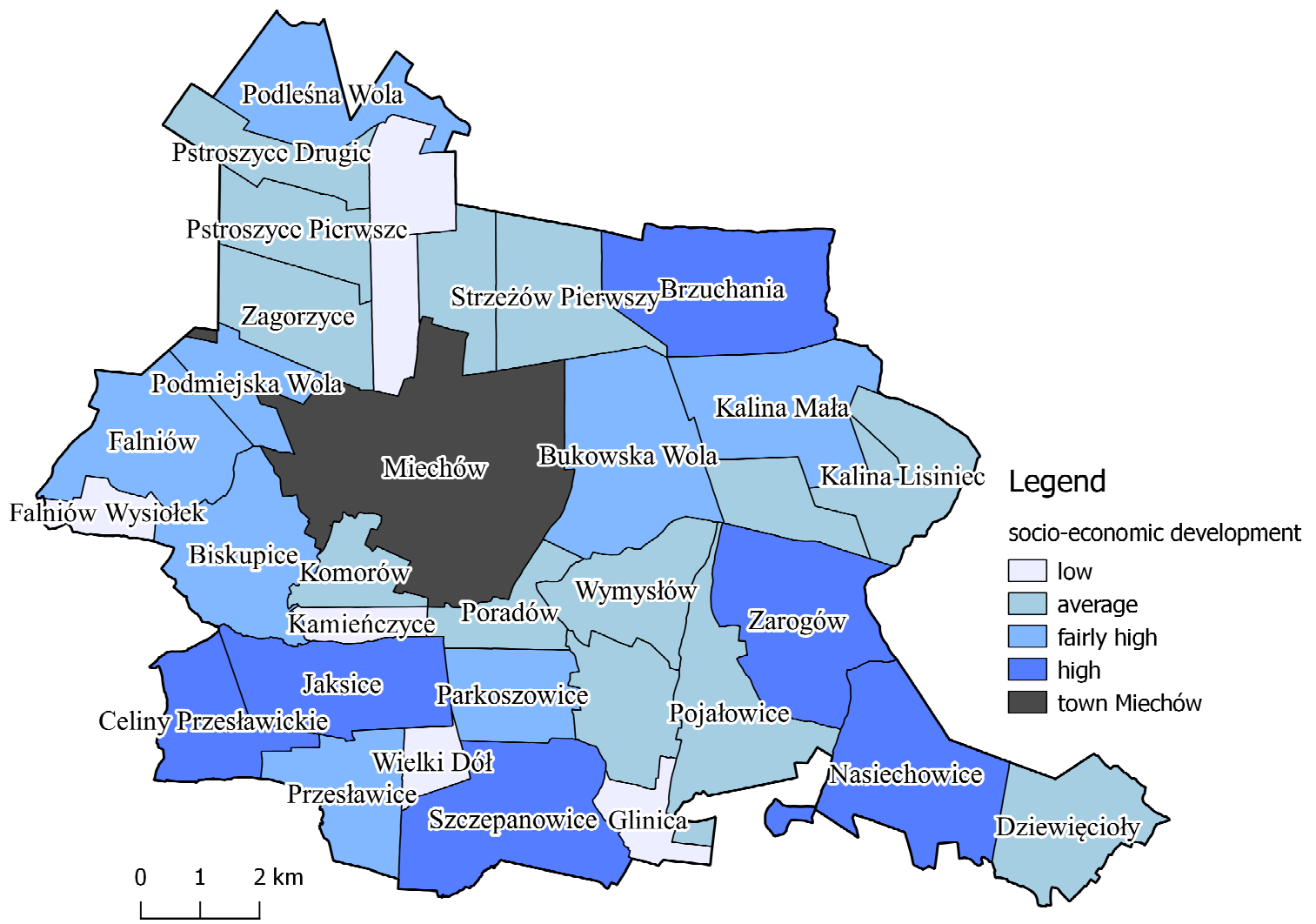

Fig. 2. Socio-economic coefficient in settlement units of Miechów commune

The places located peripherally in relation to Miechów demonstrate the high level of development as in Figure 2. So, it cannot be stated on the basis of the performed analyses that close vicinity of urban area influenced the level of development in the analysed case [12]. In this case, the distance from the city makes a barrier for relocation of people. The units situated further from the city center formed their own supports for social infrastructure providing basic requirements of citizens without going to a higher unit.

\section{Conclusions}

1. The analyzed example shows that the function fulfilled by a settlement unit in the settlement network hierarchy does not depend on the unit area or its spatial type of housing (building arrangement in relation to the transport system).

2. The tested units were divided into these with high developmental potential and with a weak one according to the level of socio-economic development of the analysed units. Miechów as the higher unit is characterized by the highest level of development. The units with a lower level of development are located in its close vicinity. Proximity of the city results in the fact that the units perform only the function of ,,a bedroom". Instead, they did not form functions that provide citizens' services. The places located in a bigger distance from the city 
are characterized by a higher level of development. In this case, the distance is a barrier for relocation of people. These units created their own basic system of inhabitants' services.

3. The greatest amount of units is characterized by the average level of development. They are located in the intermediate zone between a city with high level of development and rural units with high level of development.

4. The analysis of relations between the level of socio-economic development and a function fulfilled by a unit in the hierarchy of the functional structure of the rural settlement network revealed statistically significant, high and positive correlative relation. It means that together with the increase of the unit development level, their position in the functional structure of the rural settlement network also raises.

5. The results of the analysis can serve for the commune authorities to arrange knowledge concerning the degree of development of individual administrative units and also to take decisions regarding implementation of future programmes of development in order to compensate the existing disparities.

\section{References}

1. McGranahan G., Mitlin D. Learning from Sustained Success: How Community-Driven Initiatives to Improve Urban Sanitation Can Meet the Challenges. World Development. Vol. 87, 2016, pp. 307-317.

2. Diener E., Suh E. Measuring Quality of life: economic, social and subjective indicators. Social Indicators Research, 1997, Vol. 40, Issue 1, pp. 189-216.

3. Magnus F., Magnus L. Assessing interventions supporting sustainable development in rural areas - a dialogical approach. Nordic View to Sustainable Rural Development, 25th NJF Congress on Nordic View to Sustainable Development, Riga, Latwia, June 2015, pp. 440-444.

4. Sobczyk W. Sustainable development of rural areas. Problemy ekorozwoju, Vol. 9, Issue 1, pp. 119-126.

5. Kates R. W., Parris T. M., Leiserowitz A. A.: What is sustainable development? Goals, Indicators, Values and Practice. Environment: Science and Policy of Sustainable Development, 2005, No 47 (3). pp. 8-23.

6. de Graaf H.J., Noordervliet M.A.V., Musters C.J.M. et al. Roadmap for interactive exploration of sustainable development opportunities: The use of simple instruments in the complex setting of bottom-up processes in rural areas, Land Use Policy, 2009, Vol. 26, Issue 2, pp. 295-307.

7. Semenova N. N., Busalova S. G., Eremina O. I., Makeikina S. M., Ivanova I. A. Assessment of Sustainable Development of Rural Areas of Russia. Indian Journal of Science and Technology, 9 (14), 2016, pp. 1-7.

8. Petrick M., Buchenrieder G. Sustainable rural development: What is the role of the agri-food sector? Studies on the Agricultural and Food Sector in Central and Eastern Europe, 39, 2007, pp. 18-27.

9. Torre A., Wallet E. Innovation and governance of rural territories [In:] E. Cloudel, H. Devautour H., C. T. Soulard, G. Faure, B. Hubert (Eds.) Renewing Innovation Systems in Agriculture and Food: How to get towards more sustainability? Wageningen Academic Publishers, 2013.

10. Lanfranchi M., Giannetto C. Sustainable development in rural areas: The new model of social farming. Quality - Access to Success, 15, 2014, pp. 219-223.

11. Sharp J.S., Agnitsch K., Ryan V., Flora J. Social infrastructure and community economic development strategies: the case of self-development and industrial recruitment in rural Iowa. Journal of Rural Studies, Vol. 18, Issue 4, 2002, pp. 405-417.

12. Bilan Y., Chmielewska B. Diversified economic and social situation of farms of the European Union as a determinant of the rural areas growth policy. Actual Problems of Economics. 2013; 2(10), pp. 213-221.

13. Duncan C. Worlds Apart: Why Poverty Persists in Rural America, Yale University Press, New Haven CT, 1999.

14. Blanpain R., Auer P. (eds.), Confronting globalization: The Quest for a Social Agenda, Geneva Lectures, Kluwer Law International. 66 p.

15. Szymańska D. Geografia osadnictwa. Wydawnictwo Naukowe PWN. Warszawa, 2009. 398 p. 
16. Dziewoński K. Analysis of settlement Systems: the State of Art. Regional Science Association Papers vol. 40, 1978, pp. 39-49.

17. Kiełczewska-Zaleska M. Mapa typów morfogenetycznych osadnictwa wiejskiego, 1956, [In:] J. Tkocz, Organizacja przestrzenna wsi w Polsce. Prace Uniwersytetu Śląskiego, Katowice 1998, $179 \mathrm{p}$.

18. Chilczuk M. Mapa regionów typów kształtów osadnictwa wiejskiego w Polsce, 1970, [In:] J. Tkocz, Organizacja przestrzenna wsi w Polsce. Prace Uniwersytetu Śląskiego, Katowice 1998, $178 \mathrm{p}$.

19. Sokołowski D.: Zróżnicowanie zbioru małych miast i większych osiedli wiejskich w Polsce w ujęciu koncepcji kontinuum wiejsko-miejskiego. Wyd. UMK, Torun 1999, 31 p.

20. Głaz M.: Przekształcenia agrarne strefy podmiejskiej jako efekt oddziaływania miasta Wrocławia. [w:] J. Słodczyk, R. Klimek (red.), Przemiany przestrzeni miast i stref podmiejskich. Uniwersytet Opolski, Opole 2006, pp. 153-166.

21. Gonda-Soroczyńska E.: Czy to jeszcze wieś? Polskie Krajobrazy Dawne i Współczesne. Prace Komisji Krajobrazu Kulturowego Nr 12. Komisja Krajobrazu Kulturowego PTG, Sosnowiec, 2009, pp. 178-189.

22. Gwiazdzinska-Goraj M., Goraj S. The Contribution of the Natural Environment to Sustainable Development on the Example of Rural Areas in the Region of Warmia and Mazury, 6th International Scientific Conference on Rural Development - Innovations and Sustainability Location, Rural Development 2013, Vol. 6, Book 3, pp. 266-271.

23. Horlings I., Padt F. Leadership for Sustainable Regional Development in Rural Areas: Bridging Personal and Institutional Aspects. Sustainable Development, Vol. 21, Issue 6, 2013, pp. 413-424.

24. Kolenda M., 2006, Taksonomia numeryczna: klasyfikacja, porządkowanie i analiza obiektów wielocechowych, [Numerical taxonomy. Classification, organization and analysis of multivariate objects], Wyd. Akademii Ekonomicznej we Wrocławiu, pp. 359.

25. Ziemiańczyk U. Ocena poziomu rozwoju społeczno-gospodadrczego gmin wiejskich i wiejskomiejskich w woj. małopolskim. Infrastruktura i Ekologia Teranów Wiejskich nr 14, 2010, pp. 31-40.

26. Maya Frades A., Hidalgo Gonzalez C. New functions and developments in European rural areas: the need to adapt to long-term sustainable production methods, Boletin de la Asociacion de Geografos Espanoles, 2009, Issue 49, pp. 255-261. 